with strong Brønsted acids, though in poor yields ${ }^{[3]}$. However, the trifluoromethanesulfonic-carboxylic anhydrides obtainable from acyl chlorides and $\mathrm{CF}_{3} \mathrm{SO}_{3} \mathrm{H}$ do smoothly acylate aromatic compounds without addition of a catalyst ${ }^{[4]}$; in the course of the reaction, the sulfonic acid is set free again. Therefore, $\mathrm{CF}_{3} \mathrm{SO}_{3} \mathrm{H}$-catalyzed acylation of

aromatic compounds with acyl chlorides appeared a possibility.

If a catalytic amount $(\sim 1 \%)$ of $\mathrm{CF}_{3} \mathrm{SO}_{3} \mathrm{H}$ is added to a mixture of acyl chloride (1) and aromatic compound (2), hydrogen chloride is evolved more or less violently, depending on the reactivity of the reactants, and aromatic ketones (3) (Table 1) are formed.

In many cases carboxylic anhydrides may be made to react under similar conditions, but the yields are then slightly lower.

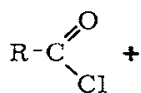

(1)<smiles>[R1]c1ccccc1</smiles>

(2)<smiles></smiles><smiles>[R]C(=O)c1ccc([R7])cc1</smiles>

(3)

Table 1. Formation of aromatic ketones by catalytic Friedel-Crafts acylation.

\begin{tabular}{|c|c|c|c|c|c|c|}
\hline \multicolumn{2}{|c|}{ Reactants } & \multicolumn{2}{|c|}{ Conditions } & \multirow[t]{2}{*}{ Product } & \multirow{2}{*}{$\begin{array}{l}\text { Yield } \\
(\%)\end{array}$} & \multirow[t]{2}{*}{$o: p$} \\
\hline (l), $\mathrm{R}$ & (2) & $T\left({ }^{\circ} \mathrm{C}\right)$ & $t(\mathrm{~h})$ & & & \\
\hline $\mathrm{C}_{6} \mathrm{H}_{5}$ & Benzene & 80 & 8.5 & Benzophenone & 14 & \\
\hline $\mathrm{C}_{6} \mathrm{H}_{5}$ & Chlorobenzene & 132 & 5 & 2- and 4-Chlorobenzophenone & 13 & $1: 3$ \\
\hline $\mathrm{C}_{6} \mathrm{H}_{5}$ & Toluene & 110 & 48 & 2- and 4-Methylbenzophenone & 85 & $1: 2$ \\
\hline $\mathrm{C}_{6} \mathrm{H}_{5}$ & $p$-Xylene & 138 & 6 & 2,5-Dimethylbenzophenone & 82 & \\
\hline$p-\mathrm{NO}_{2}-\mathrm{C}_{6} \mathrm{H}_{4}$ & Benzene & 80 & 4 & 4-Nitrobenzophenone & 82 & \\
\hline$\left(\mathrm{CH}_{3}\right)_{3} \mathrm{C}$ & Anisole & 154 & 12 & $t$-Butyl $p$-methoxyphenyl ketone & 54 & \\
\hline$\left(\mathrm{CH}_{3}\right)_{2} \mathrm{CH}$ & Anisole & 154 & 0.2 & Isopropyl p-methoxyphenyl ketone & 46 & \\
\hline
\end{tabular}

\section{Catalytic Friedel-Crafts Acylation of Aromatic Compounds $^{[1]}$}

By Franz Effenberger and Gerhard Epple ${ }^{\left.\left.\right|^{*}\right\rfloor}$

For the synthesis of aryl ketones from aromatic compounds and acid chlorides or anhydrides at least one equivalent of Friedel-Crafts catalyst is required ${ }^{[2]}$. Highly activated arenes such as mesitylene or anisole may be acylated also

[*] Prof. Dr. F. Effenberger and Dipl.-Chem. G. Epple Institut für Organische Chemie der Universität 7000 Stuttgart, Azenbergstrasse 14-18 (Germany)
Trifluoromethanesulfonic-carboxylic anhydrides ${ }^{14]}$ formed as intermediates could be assumed to constitute the active acylating agent; on the other hand, the acylating potential of the acyl chlorides may also be increased sufficiently by protonation of the $\mathrm{C}=\mathrm{O}$ group. We have therefore studied the catalytic efficiency of other strong Brønsted and Lewis acids. As shown in Table 2, catalytic acylation of arenes is possible in principle also with other acids; the yields, though, are of little preparative interest. Perchloric acid which has about the same acid strength as trifluoromethanesulfonic acid ${ }^{[5]}$ is a considerably less effective catalyst. This finding supports our assumption that intermediate 
formation of mixed anhydrides is decisive for the catalytic influence of trifluoromethanesulfonic acid; a final decision, however, is not yet possible.

Table 2. Catalytic action of Brønsted and Lewis acids in the acylation of $p$-xylene by benzoyl chloride.

\begin{tabular}{llccc}
\hline Catalyst & Amount & \multicolumn{2}{c}{ Conditions } & Yield \\
& $(\%)$ & $T\left({ }^{\circ} \mathrm{C}\right)$ & $t(\mathrm{~h})$ & $(\%)$ \\
\hline $\mathrm{CF}_{3} \mathrm{SO}_{3} \mathrm{H}$ & 1 & 138 & 6 & 82 \\
$\mathrm{FSO}_{3} \mathrm{H}$ & 1 & 138 & 6 & 20 \\
$p-\mathrm{CH}_{3}-\mathrm{C}_{6} \mathrm{H}_{4}-\mathrm{SO}_{3} \mathrm{H}$ & 1 & 138 & 6 & 31 \\
$\mathrm{H}_{2} \mathrm{SO}_{4}$ & 1 & 138 & 6 & 28 \\
$\mathrm{HClO}_{4}$ & 1 & 138 & 6 & 14 \\
$\mathrm{CF}_{3} \mathrm{COOH}$ & 2.6 & 138 & 10 & 21 \\
$\mathrm{HPOF}_{2}$ & 3.1 & 138 & 10 & 4 \\
$\mathrm{AlCl}_{3}$ & 2 & 138 & 15 & 26 \\
$\mathrm{SnCl}_{4}$ & 2 & 138 & 15 & 30 \\
\end{tabular}

\section{2,5-Dimethylbenzophenone:}

Benzoyl chloride $(42 \mathrm{~g})$ and p-xylene $(95.5 \mathrm{~g})$ are mixed and treated with trifluoromethanesulfonic acid $(0.42 \mathrm{~g})$, then heated for $6 \mathrm{~h}$ under reflux. After cooling, the reaction mixture is washed several times with water, dried over sodium sulfate and fractionated, yielding $82 \%(51.6 \mathrm{~g})$ of 2,5-dimethylbenzophenone, b.p. $173-175^{\circ} \mathrm{C} / 12$ torr. For recovery of the catalyst, the aqueous phases are neutralized with barium carbonate, and evaporated.

Received: December 16, 1971 [Z $579 \mathrm{~b}$ IE] German version: Angew. Chem. 84, 295 (1972)

[1] Electrophilic Substitution of Aromatic Compounds, Part 2.Part 1: [4].-This work was supported by the Deutsche Forschungsgemeinschaft and the Fonds der Chemischen Industrie.

[2] See G. A. Olah: Friedel-Crafts and Related Reactions. Interscience, New York 1964, Vol. 3, pp. 8 ff.

[3] a) F. Unger, Liebigs Ann. Chem. 504, 267 (1933); b) R. E. Foster, US-Pat. 2496786 (1950), E.I. du Pont de Nemours; Chem. Abstr. 44, $4930^{\circ}$ (1950): c) G. N. Dorofeenko. Zh. Obshch. Khim. 3l, 994 (1961).

[4] F. Effenberger and G. Epple, Angew. Chem. 84, 294 (1972); Angew. Chem. internat. Edit. 11,299 (1972).

[5] Th. Gramsted, Tidsskr. Kjemi, Bergvesen Met. 19, 62 (1959); Chem. Abstr. 54, 12739 (1960) 